\section{КЛАССИФИКАЦИЯ БУХГАЛТЕРСКОГО АУТСОРСИНГА:} СООТВЕТСТВИЕ СОВРЕМЕННЫМ ТЕНДЕНЦИЯМ РАЗВИТИЯ

Проведен анализ существующих на сегодняшний день классификаций бухгалтерского аутсорсинга. Сделана оценка определенных учеными классификационных признаков на соответствие потребностям в обеспечении эффективности бухгалтерского аутсорсинга. Предложено осуществлять его классификацию по следующим признакам, представленных в трех группах: в зависимости от предоставляемых услуг; в зависимости от субъектов хозяйствования и в зависимости от требований к организации аутсорсинга.

Ключевые слова: бухгалтерский аутсорсинг, организация бухгалтерского учета, классификация бухгалтерского аутсорсинга.

Liakhovych Halyna, PhD, Associate Professor Director IvanoFrankivsk Institute of Management Studies of the Ternopil National Economic University, Ukraine, e-mail: kaffinance@ukr.net, ORCID: https://orcid.org/0000-0002-0077-9128

\section{Mykolaichuk I., Sylkina Y., Sychova $\mathbf{N}$.}

\title{
INVESTIGATION OF SOCIALLY RESPONSIBLE BEHAVIOR OF TRADE ENTERPRISES ON A COMPETENT- BASED APPROACH
}

Досліджено сутність та значення сочіальної відповідальності підприємства як наукової концепиії. Визначено складові соціальної відповідальності підприємства. Розглянуто особливості становлення соціально-відповідальної поведінки підприємств торгівлі на сучасному етапі їх функиіонування. Виконано аналіз сутності компетентного підходу як методу наукового-практичного аналізу соціально-економічної системи в чілому, так методу впливу на індивідуальну поведінку підприємства торгівлі, зокрема.

Ключові слова: сочіальна відповідальність, сочіально-відповідальна поведінка підприємства торгівлі, компетентнісний підхід, компетенції підприємства.

\section{Introduction}

Globalization challenges, the main cause of which is the general decline in the volume of national production and the crisis phenomena in all spheres of economic activity, negatively affected the state of Ukraine's domestic trade, has recently undergone significant changes under the influence of crisis phenomena. Despite the difficult economic and political situation, trade is characterized by a slight decline in performance indicators compared to other spheres of economic activity. Due to significant political and economic transformations, the country's demand for goods and services is declining. In turn, this leads to a decrease in the profits of trade enterprises, causes an imbalance in the demand and supply of the consumer market, caused by the mismatch of social production and the unstable development of trade and intermediary activities. At the same time, the principles of responsible behavior become a significant competitive advantage of their activity and increase of business reputation in the region, taking into account the social orientation and significance for the consumers of the enterprise and for each employee as much as possible. Their definition is based on various scientific approaches and assessment methods, one of which is the competence approach, is spreading in connection with the need to develop the skills of managers to successfully solve operational and strategic socially significant tasks for the survival and competitiveness of enterprises. Taking this into account, research on the socially responsible behavior of trade enterprises is an urgent problem, determines the formation and development of their specific advantages in the Ukrainian business environment.

\section{The object of research and its technological audit}

The object of research is the problems of the formation of social behavior of trade enterprises at the present stage of their functioning and development. Increasing the level of competitiveness of trade enterprises is determined by many factors, including their accumulated potential, the basis of which is the formation of organizational competencies. The practice of the functioning of trade enterprises testifies to existing problems in the stability of contractual relations with business partners, in increasing current operating costs, capitalization of enterprises, changes in the qualitative and quantitative composition of personnel, dissatisfaction of workers in the system of motivation and working conditions, and the like.

In this regard, increasing the level of competitive advantage to enterprises along with other methods can ensure compliance with the principles of social responsibility to the society, consumers and workers themselves. One of the most problematic areas in the outlined problems of the study is the use of a competence approach to the formation of socially responsible behavior of trade enterprises, based on the principles of identifying the most significant socially-oriented activities of competition and survival in the market. 


\section{The aim and objectives of research}

The aim of research is analysis of the theoretical, methodological and practical problems of the formation of socially responsible behavior of trade enterprises for a competent approach.

To achieve this aim, it is necessary to perform the following tasks:

1. To consider the essence of the social responsibility of business as a scientific concept.

2. To analyze the factors of the functioning and development of trade enterprises in Ukraine.

3. To identify the essence and competitive advantages of a socially responsible enterprise.

4. To formulate a model of the process of managing the socially responsible behavior of a commercial enterprise on the basis of a competence approach.

\section{Research of existing solutions of the problem}

The problem of «social responsibility» as a philosophical category, and in the future as a socio-economic category, is the subject of research by many world scientists. In [1-5], issues of interaction between business and society, as well as building relationships between enterprises and stakeholders, are examined, as well as the social responsibility of enterprises as a factor of their economic development and competitiveness. In the sphere of economics, the principle of business responsibility for social development was first formulated in [1]. Scientific research [6-8] is devoted to the issues of forming competencies of enterprises as the basis of their competitive advantages. The paper [9] thoroughly studies the models and management practice of corporate social responsibility in different countries and examines the factors and opportunities for its development in Ukraine. Diagnostics of the state and prospects for the development of social responsibility in Ukraine is carried out by a number of scientists, among which it is worth mentioning the works [10-12]. The work [13] is devoted to the development of a mechanism for managing socially responsible enterprise activity. Aspects of formation and directions for the implementation of socially responsible management at trade enterprises are discussed in [14], which authors thoroughly described social responsibility as a component of the implementation of the corporate development strategy.

Thus, the results of the analysis allow to conclude that the problem of socially responsible behavior of enterprises is the subject of research of many scientists, however, the issues of the social development of trade enterprises on the basis of a competence approach remain important.

\section{Methods of research}

The theoretical basis for the work is methodological approaches to the conceptual essence of socially responsible behavior in the practice of Ukrainian enterprises, including the materials of the periodical press and Internet resources. In the process of their processing, when studying the essence and components of socially responsible behavior of the enterprise, such scientific methods are used:

- methods of analysis and synthesis - when analyzing numerous scientific studies and identifying common conceptual approaches;
- method of systematization - to study trends in the formation and development of socially responsible behavior of trade enterprises;

- analytical and systematization method - to identify the most significant factors in the formation of socially responsible behavior of trade enterprises;

- method of generalization - a model of the process of managing the socially responsible behavior of a trade enterprise on the basis of a competence approach.

\section{Research results}

The study of scientific approaches to the definition of the essence of the concept of «social responsibility of business» (SRB) in [9-14] has shown that there is no single generally accepted definition of this category in international and Ukrainian practice, and there are no unified approaches to the interpretation of the subject and principles of responsible activity enterprises and individual workers. In the economically developed countries of the world, the concept of social responsibility has spread, the meaning of which is the conscious attitude of business entities to the requirements of social necessity, social tasks, moral and ethical norms and values. And also understanding the consequences of their activities for society, the state, consumers, business partners and their employees.

The social responsibility of business is understood as the responsible attitude of any company to its product or service, consumers, employees, partners, the active social position of the company, which consists in harmonious coexistence, interaction and constant dialogue with society, participation in solving acute social problems [12].

According to the results of numerous studies, the current unstable and difficult conditions for managing trade enterprises in Ukraine are characterized by the following factors [15]:

- unstable political situation in the country;

- exacerbation of inflation, significant fluctuations in the exchange rate of the national currency and uncertainty in the currency exchange rate policy of the state;

- limited consumer demand and low purchasing power

of the population due to reduced income;

- difficult conditions for business lending and high interest rates on loans;

- constant increase in prices for basic goods and services;

- decrease in the volume of Ukrainian production and an increase in the cost of imported products as a result of the devaluation of the hryvnia;

- imperfect legislative base in the system of taxation of enterprises and the development of a spontaneous market;

- insufficiency of retail space, deficit of trade shelves and high rent for retail space;

- insufficiently complete and high-quality customer service.

In the presence of such economic conditions, the functioning and development of trade enterprises has certain difficulties in the processes of formation of procurement policy and pricing, credit and financial policies and in the formation of active personnel and social policies.

The sphere of trade remains a significant factor in the socio-economic development of Ukraine, as it provides 
numerous jobs. So, as of January 1, 2015, the number of employed workers at trade enterprises was $21.9 \%$ of the total number of employees in various types of activities of individuals in Ukraine, which is the largest indicator among other industries. The functioning of trade enterprises makes a significant contribution to the domestic national product. Thus, the volume of sold services for the three quarters of 2015 amounted to 447,274 million UAH or $121.6 \%$ to the corresponding period of 2014 [16] and makes a significant contribution to the domestic national product.

According to the results of the International audit and consulting company «Deloitte», in the «Retail trade» sub-sector among the leaders in the market six Ukrainian retail trade companies are defined: «ATB-market», FozzyGroup, «Epicenter K», «Foxtrot», «Auchan Ukraine», «Furshet». According to the company, «Among the retail chains, the national discounter ATB-market is the most distinguished, its revenues grew by $26 \%$ against $1.1 \%$ on average in the industry the result is mainly due to the fact that Ukrainians continue to save and are more attentive to prices on food. This trend will continue in the future» [17].

The company, which reduced its revenues to $4.0 \%$ the previous year, but still gets the leader's position, is named Foxtrot, and the company, which became the leader with a constant income level of $0.0 \%$, compared to the previous year - Furshet.

Among the negative factors of the low level of social and innovative activity of retail enterprises, the following should be singled out at the present stage [18]:

- slow consumer demand of the Ukrainian retail mar-

ket, the high cost of renting retail space and, as a consequence, low profitability;

- slowdown in the country's economic growth, a tight budget policy and a decline in confidence in the institutions of state power;

- political instability, high inflation, weak development and closure of the retail real estate market impossible to implement the plans of global retail networks for their development in Ukraine;

- low level of their investment attractiveness - due to imperfection of the infrastructure.

When examining the current state of retail trade, there are also positive trends, including: expansion of national retail networks, increase in the share of own brands in FMCG retail, and the establishment of the e-commerce market. Features of the functioning of trade enterprises is their direct interaction with consumers of goods and services, the maximum approximation to their needs, the ability to establish and develop relationships with consumers and the like. Under such conditions, trade enterprises become, on the one hand, sensitive to changes in the preferences and sentiments of the representatives of the concerned parties, and on the other hand, they are quite influential in the social situation.

From the position of the management category, a socially responsible trade enterprise is an economic entity that provides professional services to consumers for profit, implementing social responsibility principles in its activities.
The social responsibility of the enterprise of trade provides for an integrated approach to improving management effectiveness. Minimizing the risks associated with interaction with the external environment allows the enterprise to gain competitive advantages in the market. Direct influence on the formation of the competitive advantages of the enterprise can be obtained through the characteristics shown in Fig. 1. 
participates in the process of servicing consumers and is objectively characterized by a high level of social orientation. But in conditions of financial and economic crisis, most enterprises in the sphere of services reduce the costs of professional development of workers, creating safe working conditions for them, decent pay and social packages of personnel, mainly leading to a weakening of their competitiveness level. Based on the concept of socially responsible enterprise management, it should be noted that in the organization of labor of a trade enterprise, significant changes occur in the place and role of personnel in the process of servicing consumers. The socially responsible attitude of managers to their own personnel is characterized not only by the methods of forming attachment and preserving the loyalty of employees, but also manifests itself with regard to the release of personnel. A common practice of trade enterprises in modern business conditions is a «consumer» approach to personnel: if necessary, they attract and use, and if a positive effect is lost, «unnecessary» workers are fired. This approach does not comply with the principles of socially responsible management and leads to a deterioration of the company's image in the consumer market and labor market. The way out of this situation should be the use of the technique of correct personnel release, according to which the personnel should be treated as a partner and the release procedure should be carried out correctly with the maximum understanding of the situation of each person.

A socially responsible trade enterprise (SRTE) is becoming an increasingly important component of the formation of its positive image from the standpoint of stakeholders. In favor of this thesis is evidenced by the information of the leading enterprises of the world that have joined the Global Compact (GC) and carry out their activities on the principles of social responsibility. By their behavior they have proved that only those enterprises that use ethical approaches in their activity as a whole to society as a whole, and for employees, can be reliable partners, respecting them and creating the necessary working conditions. Conversely, cooperation with enterprises does not recognize the terms of the Global Compact, is associated with additional risks. This is explained by the fact that interaction with enterprises that do not adhere to the principles of professional and socially responsible ethics in the modern market with fierce competition is becoming increasingly risky and unpredictable [21].

For a number of interrelated factors and factors of influence on the development of the competencies of the trade enterprise, a model of the process of managing the socially responsible behavior of a trade enterprise (SRBTE) has been formed (Fig. 2).

The proposed SRTE model allows combining various types of its potentials for the formation of competencies and, through the synergy effect, effectively using them.

Analyzing the types of competencies of the enterprise in terms of their importance for the development of the enterprise, it is worthwhile to note that the competence of the employees is a significant component of the organization's competencies, on the level of which the level of competitiveness of the organization on the market depends substantially.

The notation in Fig. 2:

$P_{\text {soc. act. }}$ - social activity level;

$P_{i}$ - expert evaluation of the use of the $i$-th element of the potential (points);

$W_{i}$ - coefficient of weight of the $i$-th element of the potential;

$I I_{i}$ - integral indicator of key competencies of the $i$-th enterprise;

$a_{j}$ - coefficient of weight of the $j$-th index;

$p_{i j}$ - the standardized value of the $j$-th partial indicator of the $i$-th analyzed enterprise.

The competence of a socially responsible trade enterprise (SRTE) is a set of knowledge and skills of management and employees of the enterprise in observance of the principles of social responsibility, which give the enterprise and its services distinctive characteristics and ensure recognition and an individuality containing corporate symbols and other defining features. In turn, it contributes to the development of the social capital of the enterprise a collection of actual or potential resources associated with owning a stable network of more or less institutionalized relations of mutual acquaintance or recognition.

The competence of employees, as a rule, is a logical consequence of the core competencies of the enterprise, business strategy and ensures the implementation of business processes and projects.

\section{Stage 1 - assessment of the competencies of the enterprise}

Determination of the level of social activity of enterprises using the appropriate coefficient: $P_{i s o c \text {. act. }}=\left(P_{i} \times W_{i}\right)$

Stage 2 - calculation and methodical

Calculation of the integral indicator of key competencies of the trade enterprise:

$$
I I_{i}=\sum_{j=1}^{n} a_{j} p_{i j}
$$

\begin{tabular}{|c|}
\cline { 2 - 3 } \multicolumn{1}{c|}{ Stage 3-project } \\
\hline Formation of socially responsible behavior and definition of \\
perspective directions of social and economic development and increase of \\
competitiveness of the trade enterprise
\end{tabular}

Fig. 2. The model of the process of managing a socially responsible trade enterprise (5RTE) by a competent approach (compiled by the authors) 
On the other hand, personal competencies are the foundation for the competencies of the enterprise, determines the requirements for the formation of professional skills and social characteristics of employees who are called upon to implement the socio-economic mission [22].

SRTE for personnel is primarily reduced to the creation of prerequisites for a high quality of working life and the development of personnel in a combination of managerial activities aimed at increasing the level of competence of employees, taking into account their personal abilities on the basis of their professional development. One of the main objectives of the company for personnel development is creation of the conditions under which all possible reserves for the growth of the potential of employees will be realized and their high motivation to achieve the objectives of production will be ensured [23].

Analyzing the research materials on the problems of the SRTE development [7, 8, 16], it can be concluded that for most enterprises that position themselves as socially responsible, the responsibility for personnel is mainly in the elementary observance of labor legislation, namely:

- in the official registration of employees for work;

- timely payment of wages;

- conducting in-house training of personnel and granting leave of at least the same duration as are legally established and the like.

\section{SWOT analysis of research results}

Strengths. The application of the SRTE concept for a competent approach will contribute in general:

- organizational development of the enterprise of trade

in the market and ensuring its competitive advantages;

- increase of its social activity and attractiveness for stakeholders;

- achievement of positive synergies in the implemen-

tation of the personnel development project.

Weaknesses. A socially responsible trade enterprise can build its behavior on the basis of both organizational competencies and the level of competence of managers, the formation of which is conditioned by their individual qualities and leadership styles, the ability to make effective decisions on the strategic development of the enterprise.

Opportunities. The development of socially responsible behavior of a trade enterprise and its competitive position on the market, first of all, depends on the level of staff development, covering a wide range of interrelated psychological, pedagogical, social and economic problems. In this regard, it is advisable to conduct an analysis of the level of development of the competence of personnel, assistance in general to the formation of the SRTE concept. At the same time, the problem of the social activity of a trade enterprise requires close attention, it turns out to be in carrying out various social programs, the peculiarities of which can be increased in the trade in social efficiency and the level of personnel motivation in accordance with the enterprise development strategy.

Threats. The competent approach to the formation of SRTE model depends essentially on the variability and uncertainty of the external environment, including changes in the political and economic situation in Ukraine, international factors of enterprise cooperation, globalization factors. Under such conditions, at trade enterprises, it is necessary to conduct constant monitoring of the influence of the external environment, attracting external business consultants to cooperate, which may bring additional costs for the payment of their services.

\section{Conclusions}

1. As a result of the research it is shown that socially responsible activity in the modern world is a generally accepted tradition, which is adhered to by a significant number of large, medium and even small enterprises of various fields of activity. Under the social responsibility of business, one must understand:

- responsible attitude of any company to its product or service, to consumers, employees, partners;

- an active social position of the company, which consists in harmonious coexistence, interaction and constant dialogue with society, participation in solving acute social problems [12].

2. The current state of functioning and development of trade enterprises in Ukraine has certain difficulties in the processes of formation of procurement policy and pricing, credit and financial policies and in the formation of active personnel and social policies. Considering this, a number of negative factors for reducing the level of social and innovative activity of retail trade enterprises are justified.

3. A socially responsible trade enterprise should be understood as an economic entity that provides professional services to consumers for profit, implementing social responsibility principles and creating competitive advantages due to such characteristics as: social capital, image, loyalty, reputation, competitive advantages, obtaining the principles of social responsibility.

4. The competence of the enterprise is understanding the recurring, carefully planned possibility of collective interaction, based on such combination of available resources at the disposal of the enterprise for the implementation of business processes that meet market requirements and provide it with a stable competitive position in the market. A model of the process of managing a socially responsible trade enterprise (SRTE) has been constructed for a competent approach in the aggregate of 3 stages (assessment of the company's competencies, calculation, methodical and project stages). The introduction of this model will give an insight into the importance of implementation for enterprise managers to improve competitiveness in the market.

\section{References}

1. Schnepp, G. J. Social Responsibilities of the Businessman [Text] / G. J. Schnepp, H. R. Bowen // The American Catholic Sociological Review. - 1954. - Vol. 15, No. 1. - P. 42-43. doi: $10.2307 / 3708003$

2. Carroll, A. B. Corporate Social Responsibility [Text] / A. B. Carroll // Business \& Society. - 1999. - Vol. 38, No. 3. - P. 268-295. doi:10.1177/000765039903800303

3. Kotler, P. Corporate Social Responsibility: Doing the Most Good for Your Company and Your Cause [Text] / P. Kotler, N. Lee. - John Wiley \& Sons, Inc., 2004. - 320 p.

4. Kitzmueller, M. Economic Perspectives on Corporate Social Responsibility [Text] / M. Kitzmueller, J. Shimshack // Journal of Economic Literature. - 2012. - Vol. 50, No. 1. - P. 51-84. doi:10.1257/jel.50.1.51

5. Post, J. E. Managing the Extended Enterprise: The New Stakeholder View [Text] / J. E. Post, L. E. Preston, S. Sachs // California Management Review. - 2002. - Vol. 45, No. 1. P. 6-28. doi:10.2307/41166151 
6. Mintzberg, H. Strategy Process, The - European Edition (Revised) [Text] / H. Mintzberg, J. B. Quinn, S. Ghoshal. Pearson College Div, 1998. - 1036 p.

7. Kim, J. S. Manufacturing Competence and Business Performance: A Framework and Empirical Analysis [Text] / J. S. Kim, P. Arnold // International Journal of Operations \& Production Management. - 1993. - Vol. 13, No. 10. - P. 4-25. doi:10.1108/01443579310045518

8. Sepiashvili, D. S. Model' formirovaniia i razvitiia kliuchevoi kompetentsii predpriiatiia [Text] / D. S. Sepiashvili // Rossiiskoe predprinimatel'stvo. - 2006. - No. 9. - P. 54-56.

9. Saprykina, M. A. Korporatyvna sotsialna vidpovidalnist: modeli ta upravlinska praktyka [Text]: Handbook / M. A. Saprykina, M. A. Saiensus, A. H. Zinchenko, O. M. Liashenko, H. A. Misko; ed. by O. S. Redkin. - Kyiv: Farbovanyi lyst, 2011. - 480 p.

10. Novikova, O. F. Diahnostyka stanu ta perspektyv rozvytku sotsialnoi vidpovidalnosti v Ukraini (ekspertni otsinky) [Text]: Monograph / O. F. Novikova, M. Ye. Deich, O. V. Pankova et al. - Donetsk: Institute of Industrial Economics, National Academy of Sciences of Ukraine, 2013. - 296 p.

11. Kolot, A. M. Sotsialna vidpovidalnist: teoriia i praktyka rozvytku [Text]: Monograph / A. M. Kolot et al.; ed. by A. M. Kolot. - Kyiv: Kyiv National Economic University named after Vadym Hetman, 2012. - 501 p.

12. Hohulia, O. P. Sotsialna vidpovidalnist [Text]: Monograph / O. P. Hohulia, I. P. Kudinova. - Nizhyn: Lysenko M. M., 2011. - 175 p.

13. Kolot, A. M. Sotsializatsiia vidnosyn u sferi pratsi v konteksti stiikoho rozvytku [Text]: Monograph / A. M. Kolot, O. A. Hrishnova, O. O. Herasymenko et al.; ed. by A. M. Kolot. - Kyiv: Kyiv National Economic University named after Vadym Hetman, 2010. - 352 p.

14. Zhukovska, V. M. Sotsialna vidpovidalnist yak skladova realizatsii korporatyvnoi stratehii rozvytku [Text] / V. M. Zhukovska, N. V. Sychova // Visnyk Natsionalnoho universytetu vodnoho hospodarstva ta pryrodokorystuvannia. - 2008. - No. 1 (41). P. $72-79$

15. Shumilo, O. S. Dynamics of Contemporary Development of the Retail Trade Enterprises in Ukraine [Text] / O. S. Shumilo // Business Inform. - 2014. - No. 11. - P. 171-176.

16. Economic activity [Electronic resource] // State Statistics Service of Ukraine. - Available at: \www/URL: http://www. ukrstat.gov.ua/operativ/menu/menu_e/spr.htm

17. Transformatsiia ekonomiky: vyklyky chasu. Reitynh «Deloit»: TOP-500 kompanii Tsentralnoi ta Skhidnoi Yevropy, 2015 rik [Electronic resource] // Deloitte. - September 21, 2015. Available at: \www/URL: https://www2.deloitte.com/ua/uk/ pages/press-room/research/ce-top-500-2015.html

18. Cherniavska, M. Information-analytical provision of the innovative activity of trade enterprises [Electronic resource] / M. Cherniavska // Problems and prospects of economics and management. - 2015. - No. 2 (2). - Available at: \www/ URL: http://journals.stu.cn.ua/problems_and_prospects_economics_management/article/view/65550

19. Verba, V. A. Problemy identyfikatsii kompetentsii pidpryiemstva [Text] / A. V. Verba, O. M. Hrebeshkova // Problemy nauky. - 2004. - No. 7. - P. 23-28.

20. Hamel, G. Competing for the Future [Electronic resource] / G. Hamel, C. K. Prahalad // Harvard Business Review. - JulyAugust, 1994. - Available at: \www/URL: https://hbr.org/ 1994/07/competing-for-the-future

21. Savchuk, L. M. Kompetentsii personalu v umovakh ekonomiky znan [Electronic resource] / L. M. Savchuk // Problems of a systemic approach to the economy enterprises. - 2009. Vol. 3, No. 11. - Available at: \www/URL: http://ecobio.nau. edu.ua/index.php/EPSAE/article/view/4470

22. Gouillart, F. J. Business Transformation [Text] / F. J. Gouillart, J. N. Kelly. - McGraw-Hill, 1995. - 396 p.

23. Panchenko, V. P. Kontseptualni pidkhody do rozvytku korporatyvnoi sotsialnoi vidpovidalnosti orhanizatsii na zasadakh kompetentsiinoho pidkhodu [Text] / V. P. Panchenko // Aktualni problemy ekonomiiky. - 2013. - No. 7 (145). - 2013. P. $156-161$.

\section{ИССЛЕДОВАНИЕ СОЦИАЛЬНО-ОТВЕТСТВЕННОГО ЛОВЕДЕНИЯ} ПРЕДПРИЯТИЙ ТОРГОВЛИ ПО КОМПЕТЕНТНОСТНОМУ ПОДХОДУ

Исследована сущность и значение социальной ответственности предприятия как научной концепции. Определены составляющие социальной ответственности предприятия. Рассмотрены особенности становления социально-ответственного поведения предприятий торговли на современном этапе их функционирования. Выполнен анализ сущности компетентного подхода как метода научного-практического анализа социальноэкономической системы в целом, так метода воздействия на индивидуальное поведение предприятия торговли, в частности.

Ключевые слова: социальная ответственность, социальноответственное поведение предприятия торговли, компетентностный подход, компетенции предприятия.

Mykolaichuk Iryna, PhD, Associate Professor, Department of Management, Kyiv National University of Trade and Economics, Ukraine, e-mail: mykirina@ukr.net, ORCID: http://orcid.org/00000001-7380-5000

Sylkina Yulia, PhD, Associate Professor, Department of Management, Kyiv National University of Trade and Economics, Ukraine, e-mail: solyuoleg@ukr.net,ORCID: https://orcid.org/0000-0001-5724-6333

Sychova Nina, PhD, Associate Professor, Department of Management, Kyiv National University of Trade and Economics, Ukraine, e-mail: nina.sychova@gmail.com, ORCID: https://orcid.org/00000002-8492-2605 